\title{
THE EFFECT OF PLEASE STRATEGY AND WRITING INTEREST TOWARD STUDENTS' WRITING SKILL
}

\author{
${ }^{1}$ Dewi Sartika and ${ }^{2}$ Ratna Nery \\ 1, 2 English Language Study Program Faculty of Teacher Training and Education \\ Islamic University of Ogan Komering Ilir (UNISKI) Kayuagung, \\ faizahuwieks@yahoo.co.id_ratna.nery@yahoo.co.id
}

Received on August, 18th, Revised on Oct, 18th, Published on Dec, 30th 2018

\begin{abstract}
The aims of this study are to find out whether there was a significant difference in writing achievement between the students who were taught by using PLEASE strategy and that of those who were not, to find out whether there was an effect of writing interest on the students writing skill to write descriptive text or not, and to find out whether there was an effect of writing interest on the students writing skill who were taught by using PLEASE strategy or not. The samples involved in this study were the seventh-grade students of SMP Negeri 2 Kayuagung, South Sumatera which were divided into two groups; experimental and control groups. The data were gathered by using written test and questionnaire and then were analyzed by using t-test and simple linear regression. The results showed that t-obtained $(2.57)>\mathrm{t}$-table (2.0017) with the degree of freedom $54(\mathrm{df}=56)$. It could be concluded that there was a significant difference between the students who were taught by using PLEASE strategy and that of those who were not. The next result showed that there was no effect of writing interest on the students' writing skill (the score t-obtained of the writing variable was 1.14 at a significant of 0.26 ). After the treatment, the score of the writing variable was 3.34 at a significant level of 0.003 . It indicated that there was an effect of writing interest on students' writing skills who were taught using PLEASE strategy. In conclusion, the students who were taught by using PLEASE strategy could be encouraged to have writing interest so that they could write a descriptive text based on the generic structure given.
\end{abstract}

Keywords: Please strategy, writing interest, students' writing skill, descriptive text

\begin{abstract}
ABSTRAK
Tujuan dari penelitian ini adalah untuk mengetahui apakah ada perbedaan yang signifikan prestasi menulis antara siswa yang diajar dengan menggunakan strategi PLEASE dan mereka yang tidak, untuk mengetahui apakah ada pengaruh minat menulis pada siswa. Keterampilan menulis untuk menulis teks deskriptif atau tidak, dan untuk mengetahui apakah ada pengaruh minat menulis pada keterampilan menulis siswa yang diajar dengan menggunakan strategi PLEASE atau tidak. Sampel yang terlibat dalam penelitian ini adalah siswa kelas tujuh SMP Negeri 2 Kayuagung, Sumatera Selatan yang dibagi menjadi dua kelompok; kelompok eksperimen dan kontrol. Data dikumpulkan dengan menggunakan tes tertulis dan kuesioner dan kemudian dianalisis dengan menggunakan uji-t dan regresi linier sederhana. Hasil penelitian menunjukkan bahwa t-diperoleh (2,57)> t-tabel (2,0017) dengan derajat kebebasan 54 $(d f=56)$. Dapat disimpulkan bahwa ada perbedaan yang signifikan antara siswa yang diajar dengan menggunakan strategi PLEASE dan mereka yang tidak. Hasil selanjutnya menunjukkan bahwa tidak ada pengaruh minat menulis pada keterampilan menulis siswa (skor t-diperoleh dari variabel menulis adalah 1,14 pada signifikan 0,26). Setelah perawatan, skor variabel penulisan adalah 3,34 pada tingkat signifikan 0,003. Ini menunjukkan bahwa ada pengaruh minat menulis pada keterampilan menulis siswa yang diajar menggunakan strategi PLEASE. Kesimpulannya, siswa yang diajar dengan menggunakan strategi PLEASE dapat didorong untuk memiliki minat menulis sehingga mereka dapat menulis teks deskriptif berdasarkan struktur generik yang diberikan.

Kata kunci: Tolong strategi, minat menulis, keterampilan menulis siswa, teks deskriptif
\end{abstract}




\section{INTRODUCTION}

Writing is one of the communication tools used by everyone. According to Sinurat and Alicia (2013), writing is an essential skill used to communicate besides speaking and is a process of communication that takes place between the writer and the reader. In short, writing is a way of communicating where the author provides written information without dealing directly with the reader. Moreover, writing is a very important skill for students. It is supported by Mather, Wedling, and Robberts (2009, p. 1) who state that writing is the key to success in school experiences and an important communication tool that helps students learn how to organize and organize their thoughts. Yagelski (2015, p. 21) also adds that writing is a powerful way not only to describe but also to examine, to reflect on, and to understand our thoughts, feelings, opinions, ideas, action, and experience. In other words, writing is an act of pouring out the feelings, opinions, thoughts, and ideas that the author wants to share with the reader in written form where the writing is well organized so that the reader can easily understand it.

Although writing is very important to be mastered by students, students still have difficulties in expressing their ideas in writing. As Husna, Zainil, and Rozimela (2013, p.1) explain that writing is usually regarded as the most difficult skill to learn, not only because of the needs to master many skills of English: reading, speaking, and listening but also because of the difference between the learners' native language rules and that of the language being learned. Rass (2015, p.49) also states that writing is a difficult skill for native speakers and non-native speakers because writers must be able to write it in multiple issues, such as content, organization, purpose, audience, vocabularies, and mechanics including punctuation, spelling, and capitalization. To sum up, writing English is very difficult for students to master because English is a foreign language, has different writing rules than the first language mastered by students, and involves several aspects of writing such as punctuation, spelling, and capitalization. In addition, students must also write using the right vocabulary, coherent text content, and the right text organization so that readers can understand the content of the reading properly,

In the curriculum, the junior high school students especially the seventh-grade students are required to have the ability to write various kinds of text genres such as descriptive, narrative, report, recount, and procedure texts. One of the texts that students must learn is descriptive text. Husna, Zainil, and Rozimela (2013, p. 2) 
explain that descriptive text is a text which a writer tries to picture what he is describing which is used to describe a particular thing/object, place, or person. It can be stated that descriptive text is the text that explains about objects, places, or people in detail and detail.

Based on Kompas newspaper (2011) stated the comment of Head of the Bandung Language, Hall Abdul Khak who said that the tradition of writing in Indonesia was much lower than the reading tradition, especially among the younger generation. The low tradition of writing, according to Abdul, is due to the low interest in reading. Interest in writing is under reading interest. Activities, reading and writing influence each other. Reading is a reference for writing. One cannot write if you do not like reading. As a result, the teacher must try to increase the students writing interest and writing skill by using appropriate strategies. One strategy that can be used is PLEASE strategy. According to Akincilar (2010, p.53), PLEASE is an effective strategy to improve students' ability to write paragraphs. By using this strategy, students can write paragraphs because this strategy helps students to improve and organize ideas. With PLEASE strategy, students can start writing descriptive text easily because they are directed by this strategy in 6 stages, namely Pick, List, Evaluate, Activate, Supply, End.
Furthermore, Brownell, et al (2012) argue that PLEASE strategy is a writing strategy used to produce a collection of paragraphs that are organized and integrated. By using this strategy, students will be able to write completely and use coherent sentences. It can be concluded that PLEASE strategy is very helpful for students to have an interest in writing because students write following the directions were given by PLEASE strategies so that students are not rigid in writing.

Moreover, if the students have writing interest in learning something so that they can do it correctly. As stated by Djamarah, (2008, p.133), interest in something is learning outcomes and tends to support the next learning activity. Therefore, great interest influence toward learning activities. It can be assumed that the students who have great writing interest will have a better score in terms of writing achievement.

Based on the above background, the main problems in this study are formulated as follows. 1) Is there any significant difference in writing achievement between the students who are taught by using PLEASE strategy and that of those who are not?, 2) Is there an effect of writing interest on the students' writing skill to write descriptive text?, and 3) Is there an effect of writing interest on the students writing skill who are taught by using PLEASE strategy? 


\section{METHODOLOGY}

The seventh-grade students of SMP Negeri 2 Kayuguang were taken as the subject of this study. Out of five classes of the seventh-grade students, two classes were selected as the sample of this study. The samples were selected using purposive sampling method in which the class had the same criteria in terms of a total number of the students and the same English average score (75). The selection of the experimental and control groups were done by using the lottery. Consequently, class VII.4 was selected as the experimental group and class VII.5 was selected as the control group.

Since there were two classes used, a quasi-experimental design with nonequivalent control group design. In this study, the experimental group was taught writing descriptive text by using PLEASE strategy while the control group did not give treatment.

To measure the students' writing skill, the written test was used and to check the students' writing interest toward writing, a questionnaire was used. The questionnaire was given twice to the groups; before and after the treatment.

The two raters who had the same criteria, namely have taught English for five years and had Magister Degree qualification were judged the students' descriptive writing based on an analytic scoring rubric. The rubric of writing was adapted from Brown (2007) which was consisted of content $(30 \%)$, organization $(20 \%)$, grammar $(20 \%)$, vocabulary (15\%), and mechanics (15\%).

Before analyzing the data, normality and homogeneity tests were carried out. The normality data of the test was done to detect the distribution of data in a variable used in the study. This test aimed to test the assumption that those taken from the population were normally distributed. Meanwhile, a homogeneity test was conducted to show that two or more groups of sample data came from populations that had the same variance. Homogeneity test tells whether one sample with another sample has an equation or homogeneous. This test used the Levene Statistics test technique. Testing for normality and homogeneity using the SPPS version 22 program.

The collected data was first tested for analytical requirements by performing normality tests and homogeneity tests using SPSS version 22 at a significance level of $5 \%$. After fulfilling these two conditions, the first hypothesis was analyzed using the ttest, while the second and third hypotheses were analyzed using simple linear regression. 


\section{RESULT AND DISCUSSION}

\section{The Result of Pretest and Posttest of Experimental Group}

Based on the pretest results obtained from the experimental class, the highest score was 63 , the lowest score was 29 , the mean score was 41.40 , and the standard deviation was 9.00. Based on the posttest results obtained from the experimental class, the highest score was 83, the lowest score was 33 , the mean score was 54.64, and standard deviation was 13.89. The distribution of pretest and posttest scores in the experimental class can be seen in the following table:

Table 1

Distribution Score of Pretest and Posttest Experimental Group

\begin{tabular}{|clcccc|}
\hline Score & $\begin{array}{c}\text { Level of } \\
\text { Ability }\end{array}$ & $\begin{array}{c}\text { Pretest Exp } \\
\text { Frequ- } \\
\text { ency }\end{array}$ & $\begin{array}{c}\text { Percen- } \\
\text { tage }\end{array}$ & $\begin{array}{c}\text { Prequ- } \\
\text { ency }\end{array}$ & $\begin{array}{c}\text { Percen- } \\
\text { tage }\end{array}$ \\
\hline $\begin{array}{c}\text { 81- } \\
\mathbf{1 0 0}\end{array}$ & Excellent & 0 & 0 & 2 & 7 \\
\hline $\mathbf{6 1 - 8 0}$ & Good & 1 & 4 & 8 & 29 \\
\hline $\mathbf{4 1 - 6 0}$ & Mediocre & 14 & 50 & 14 & 50 \\
\hline $\mathbf{2 1 - 4 0}$ & Poor & 13 & 46 & 4 & 14 \\
\hline $\mathbf{0 - 2 0}$ & Very Poor & 0 & 0 & 0 & 0 \\
\hline & & & & & \\
\hline
\end{tabular}

The students' pre-test in the experimental group which was displayed in Table 1 showed that no students were in excellent category, one student was in good category, fourteen students were in mediocre category, thirteen students were in poor category, and no students were in very poor category. While the students' posttest in the experimental group showed that two students were in excellent category, eight students were in good category, fourteen students were in mediocre category, four students were in poor category, and no students were in very poor category.

\section{The Result of Pretest and Posttest of Control Group}

Based on the pretest results obtained from the control group, the highest score was 73 , the lowest score was 27 , the mean score was 44.14, and the standard deviation was 13.37 .

Table 2

Distribution of Pretest and Posttest Score for Control Group

\begin{tabular}{|llcccc|}
\hline Score & $\begin{array}{c}\text { Level of } \\
\text { Ability }\end{array}$ & $\begin{array}{c}\text { Pretest Con } \\
\text { Frequ- } \\
\text { ency }\end{array}$ & $\begin{array}{c}\text { Percen- } \\
\text { tage }\end{array}$ & $\begin{array}{c}\text { Frequ- } \\
\text { ency }\end{array}$ & $\begin{array}{c}\text { Percen- } \\
\text { tage }\end{array}$ \\
\hline $\begin{array}{c}\mathbf{8 1 -} \\
\mathbf{1 0 0}\end{array}$ & Excellent & 0 & 0 & 0 & 0 \\
\hline $\begin{array}{c}\mathbf{6 1 -} \\
\mathbf{8 0}\end{array}$ & Good & 4 & 14 & 3 & 11 \\
\hline $\mathbf{4 1 - 6 0}$ & Mediocre & 10 & 35 & 14 & 50 \\
\hline $\mathbf{2 1 - 4 0}$ & Poor & 14 & 50 & 11 & 39 \\
\hline $\mathbf{0 - 2 0}$ & $\begin{array}{c}\text { Very } \\
\text { Poor }\end{array}$ & 0 & 0 & 0 & 0 \\
\hline \multicolumn{2}{|c|}{ Total } & 28 & 100 & 28 & 100 \\
\hline
\end{tabular}

Based on the posttest results obtained from the control group, the highest score was 73 , and the lowest score was 29 , the mean score was 45.54, and the standard deviation was 12.53. The distribution of 
pretest and posttest scores in the control group can be seen in Table 2 above.

The students' pretest in the control group which was displayed in Table 2 showed that no students were in excellent category, four students were in good category, ten students were in mediocre category, fourteen students were in poor category, and no students were in very poor category. While the students' posttest in control group showed that no students were in excellent category, three students were in good category, fourteen students were in mediocre category, eleven students were in poor category, and no students were in very poor category.

\section{The Result of Normality Test}

The results of the normality test for each research variables are presented as follows.

Table 3

The Result of Normality

\begin{tabular}{|lc|}
\hline \multicolumn{1}{|c|}{ Variable } & P \\
\hline Pretest experiment & 0.065 \\
\hline Posttest experiment & 0.208 \\
\hline Pretest control & 0.069 \\
\hline Posttest control & 0.063 \\
\hline
\end{tabular}

From the above data, it can be seen that the results of the normality test of the research variables both pretest and posttest variables in the experimental group and in the control group have a significant value greater than $0.05(p>0.05)$. The skill to write descriptive texts during pretest and posttest in the experimental group students was above the significant level of 0.05 , namely at the level of 0.065 and 0.208 . The results of the normality test of writing descriptive text when pretest and posttest on control group students were above 0.05 , namely at the level of 0.069 and 0.063 . It can be concluded that all variables pretests and posttests in the experimental and control groups were normally distributed.

\section{Variance Homogeneity Test}

The homogeneity test was done by pretest and posttest results in the experimental group and the control group if $\mathrm{p}>0.05$.

Table 4

Homogeneity Variance

\begin{tabular}{|c|c|c|c|}
\hline $\begin{array}{l}\text { Levene } \\
\text { Statistic }\end{array}$ & $\mathrm{df} 1$ & df2 & Sig. \\
\hline 2,456 & 3 & 108 & ,067 \\
\hline
\end{tabular}

Based on the table above, it was found that the significance of the student's writing test was 0.067 . The significance level used is $\alpha=0.05$ with the test criteria: If the value is a sig. greater than $\alpha=0.05$, the data is homogeneous. It can be concluded that students' writing score data were homogeneous.

\section{The Results of Pretest and Posttest for Experimental Groups}

The experimental group was a class of students who get learning with PLEASE 
strategy. The experimental group in this study amounted to 28 students. The following table shows a comparison of the results of the calculation between the pretest and posttest scores of the experimental group.

\section{Table 5}

Statistical Data of Pretest and Posttest Writing Descriptive Text of Experimental Groups

\begin{tabular}{|c|c|c|c|c|c|c|c|c|c|}
\hline \multicolumn{7}{|c|}{ Paired Differences } & \multirow{3}{*}{$\mathbf{t}$} & \multirow{3}{*}{ df } & \multirow{3}{*}{$\begin{array}{c}\text { Sig. } \\
\text { (2- } \\
\text { tail } \\
\text { ed) }\end{array}$} \\
\hline & & \multirow[t]{2}{*}{ Mean } & \multirow[t]{2}{*}{$\begin{array}{l}\text { Std. } \\
\text { Devia } \\
\text { tion }\end{array}$} & \multirow[t]{2}{*}{$\begin{array}{l}\text { Std. } \\
\text { Error } \\
\text { Mean }\end{array}$} & \multicolumn{2}{|c|}{$\begin{array}{l}\text { 95\% Confidence } \\
\text { Interval of the } \\
\text { Difference }\end{array}$} & & & \\
\hline & & & & & Lower & Upper & & & \\
\hline $\begin{array}{l}\text { Pair } \\
1\end{array}$ & $\begin{array}{l}\text { Postt } \\
\text { est } \\
\text { Exp } \\
- \\
\text { Prete } \\
\text { st } \\
\text { Exp }\end{array}$ & 13.60 & 13.06 & 2.47 & 8.54 & 18.67 & 5.51 & 27 & .000 \\
\hline
\end{tabular}

Based on the table above, the significance was at 0.000 . This showed that there was a significant increase in both data. In addition, it was clear that there was an increase in scores between pretest and posttest of experimental group. The average score of students when pretest was 41.04, while in the posttest was 54.64. It indicated that the mean difference between pretest and posttest was 33.60.

\section{Pretest and Posttest Results Writing Descriptive Text of Control Groups}

Control group was a class of students who did not get treatment. The control group in this study amounted to 28 students. The comparison of the results of the calculation between pretest and posttest scores in the control group can be seen in the following table.

Table 6

Pretest and Posttest Statistical Data Writing

Descriptive Text of Control Groups

\begin{tabular}{|c|c|c|c|c|c|c|c|c|}
\hline \multicolumn{6}{|c|}{ Paired Differences } & \multirow{3}{*}{$\mathbf{t}$} & \multirow{3}{*}{ df } & \multirow{3}{*}{$\begin{array}{c}\text { Sig. } \\
\text { (2- } \\
\text { taile } \\
\text { d) }\end{array}$} \\
\hline & \multirow[t]{2}{*}{ Mean } & \multirow[t]{2}{*}{$\begin{array}{l}\text { Std. } \\
\text { Deviati } \\
\text { on }\end{array}$} & \multirow[t]{2}{*}{$\begin{array}{l}\text { Std. } \\
\text { Error } \\
\text { Mean }\end{array}$} & \multicolumn{2}{|c|}{$\begin{array}{l}\text { 95\% Confidence } \\
\text { Interval of the } \\
\text { Difference }\end{array}$} & & & \\
\hline & & & & $\begin{array}{c}\text { Lowe } \\
\mathbf{r}\end{array}$ & Upper & & & \\
\hline $\begin{array}{l}\text { Posttes } \\
\text { t Con- } \\
\text { Pretest } \\
\text { Con }\end{array}$ & 1.393 & 17.328 & 3.275 & -5.326 & 8.112 & .425 & 27 & .674 \\
\hline
\end{tabular}

Based on the table above, the significance was above 0.000 . This showed that there was no significant increase in both data. In addition, the increase in scores between pretest and posttest of control group increased slightly. The average score of students when pretest was 44.14 , while in the posttest was 45.54. It indicated that the mean difference between pretest and posttest was 1.39 .

\section{Comparison of Posttest Writing Descriptive Texts for Experimental Classes and Control Groups}

After testing the results of writing descriptive text in both groups, the results of both groups were increased from pretest to posttest. The increase in the experimental group was 13.60, while the control group was 1.39. To find out which group had the most significant increase, independent sample t-test was used.

Based on the calculation of the data, the mean difference of the experimental 
group and the control group was 54.64:

$45.54=9.10$. It signified that there is a significant difference in writing achievement between the students who were taught writing descriptive text by using PLEASE strategy and that of those who were not. See Table 7.

Table 7

The Posttest Data of Statistics in the Experimental Group and Control Group

\begin{tabular}{|c|c|c|c|c|c|c|c|c|c|}
\hline & \multicolumn{2}{|c|}{$\begin{array}{l}\text { Levene's } \\
\text { Test for } \\
\text { Equality } \\
\text { of } \\
\text { Varianc } \\
\text { es }\end{array}$} & \multicolumn{7}{|c|}{ t-test for Equality of Means } \\
\hline & \multirow[t]{2}{*}{$\mathbf{F}$} & \multirow[t]{2}{*}{$\begin{array}{l}\text { Si } \\
\text { g. }\end{array}$} & \multirow[t]{2}{*}{$\mathbf{t}$} & \multirow[t]{2}{*}{$\begin{array}{l}\text { d } \\
\text { f }\end{array}$} & \multirow[t]{2}{*}{$\begin{array}{l}\mathrm{Si} \\
\mathrm{g} . \\
(2- \\
\text { tai } \\
\text { led } \\
\text { ) }\end{array}$} & \multirow[t]{2}{*}{$\begin{array}{l}\text { Me } \\
\text { an } \\
\text { Diff } \\
\text { ere } \\
\text { nce }\end{array}$} & \multirow[t]{2}{*}{$\begin{array}{l}\text { Std. } \\
\text { Err } \\
\text { or } \\
\text { Diff } \\
\text { ere } \\
\text { nce }\end{array}$} & \multicolumn{2}{|c|}{$\begin{array}{l}95 \% \\
\text { Confidence } \\
\text { Interval of } \\
\text { the } \\
\text { Difference }\end{array}$} \\
\hline & & & & & & & & $\begin{array}{l}\text { Lo } \\
\text { wer }\end{array}$ & $\begin{array}{l}\text { Uppe } \\
\text { r }\end{array}$ \\
\hline $\begin{array}{l}\text { Equal } \\
\text { variances } \\
\text { assumed }\end{array}$ & 0.71 & .79 & 2.57 & 54 & .01 & 9.10 & 3.53 & 2.01 & 16.19 \\
\hline
\end{tabular}

The table above showed that the average score of the experimental group was higher than the control group. The result of t-value was 2.57 with significance (2-tailed) of 0.013. This shows that t-obtained (2.57) was higher than t-table (2.0017) with the degree of freedom 54. By paying attention to the testing criteria, namely the probability $<0.05$, it can be concluded that Ho was rejected, while Ha was accepted. In other words, there was a significant difference between the students who were taught by using PLEASE strategy and that of those who were not.

\section{Results of Writing Interest with Writing} Ability

After the regression test, the correlation score showed that the independent variable with the dependent variable was 0.21 , the determination coefficient score showed the number of independent variable contributions to the dependent variable was 0.48 or equal to $4.8 \%$. See Table 8.

Table 8

Influence Correlation Coefficient Variable X (Writing Interest) to Variable Y (Writing Descriptive)

\begin{tabular}{|ccccc|}
\hline $\begin{array}{c}\text { Mo } \\
\text { del }\end{array}$ & R & $\begin{array}{c}\text { R } \\
\text { Square }\end{array}$ & $\begin{array}{c}\text { Adjusted R } \\
\text { Square }\end{array}$ & $\begin{array}{c}\text { Std. Error of } \\
\text { the Estimate }\end{array}$ \\
\hline 1 & $.218^{\mathrm{a}}$ & .048 & .011 & 8.91 \\
\hline
\end{tabular}

Table 9 showed sig. 0.26 and F-count 1.30 which meant that the regression coefficient of independent variables with the dependent variable was not significant. See Table 9.

Table 9

Regression of Influence Variable X (writing interest) to variable $\mathrm{Y}$ (descriptive writing)

\begin{tabular}{|c|c|c|c|c|c|c|}
\hline \multicolumn{2}{|c|}{ Model } & $\begin{array}{l}\text { Sum of } \\
\text { Squares }\end{array}$ & Df & $\begin{array}{l}\text { Mean } \\
\text { Square }\end{array}$ & $\mathrm{F}$ & Sig. \\
\hline \multirow[t]{3}{*}{1} & $\begin{array}{l}\text { Regre } \\
\text { ssion }\end{array}$ & 103.41 & 1 & 103.41 & 1.30 & $.264^{\mathrm{a}}$ \\
\hline & $\begin{array}{l}\text { Resid } \\
\text { ual }\end{array}$ & 2064.41 & 26 & 79.40 & & \\
\hline & Total & 2167.82 & 27 & & & \\
\hline
\end{tabular}

Based on Table 10, a regression equation score is obtained, the correlation coefficient is $\mathrm{Y}=22.21+0.25$, the score $\mathrm{t}$ - 
obtained the writing variable is 1.14 at a significant 0.26 . This shows that there is no independent variable relationship with the dependent variable. In other words, there is no influence of writing interest on the ability to write student descriptive texts. See Table 10.

Table 10

Significant Regression Coefficients Effect of Variable X (writing interest) on Variable Y (descriptive writing)

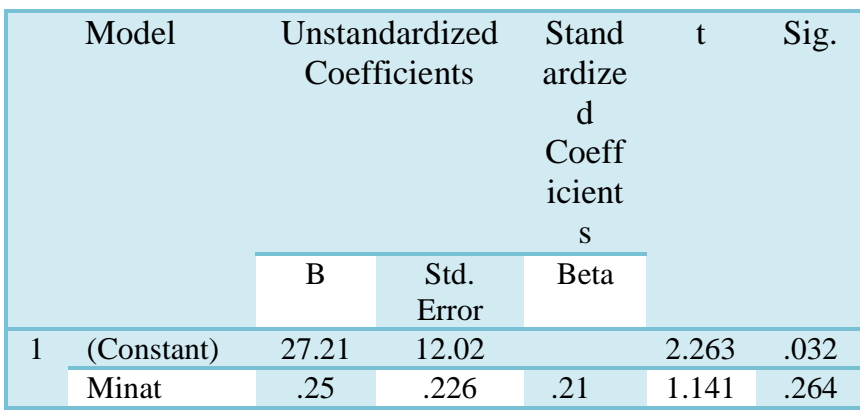

\section{Results of Writing Interest with Writing} Ability using PLEASE strategy

After the regression test, the correlation score showed that the independent variable with the dependent variable is 0.54 , the determination coefficient score shows the number of independent variable contributions to the dependent variable is 0.301 or equal to 30.1\%. See Table 11.

Table 11

Correlation Coefficient of Influence Variable X (writing interest) on Variable $\mathrm{Y}$ (writing descriptive using PLEASE strategy)

\begin{tabular}{|ccccc|}
\hline Model & $\mathrm{R}$ & $\begin{array}{c}\mathrm{R} \\
\text { Square }\end{array}$ & $\begin{array}{c}\text { Adjuste } \\
\mathrm{d} \mathrm{R} \\
\text { Square }\end{array}$ & $\begin{array}{c}\text { Std. Error } \\
\text { of the } \\
\text { Estimate }\end{array}$ \\
\hline 1 & $.548^{\mathrm{a}}$ & .301 & .274 & 11.904 \\
\hline
\end{tabular}

Table 12 showed sig. 0.03 and Fcount 11.17 which meant the coefficient independent variable regression with a significant dependent variable. See Table 12.

Table 12

The Influence of Variable $\mathrm{X}$ (writing interest) on $\mathrm{Y}$ variable (writing descriptive using PLEASE strategy)

\begin{tabular}{|lrr|ccc|}
\hline Model & $\begin{array}{c}\text { Sum of } \\
\text { Squares }\end{array}$ & Df & $\begin{array}{c}\text { Mean } \\
\text { Square }\end{array}$ & F & Sig. \\
\hline Regression & 1582.70 & 1 & 1582.70 & 11.170 & $.003^{\mathrm{a}}$ \\
\hline Residual & 3684.17 & 26 & 141.69 & & \\
\hline Total & 5266.88 & 27 & & & \\
\hline
\end{tabular}

Based on Table 13, a regression equation score is obtained, the correlation coefficient is $\mathrm{Y}=7.81+0.75$, the calculated score of the writing variable is 3.34 at a significant 0.003 . This shows that there is a relationship between the independent variable and the dependent variable. In other words, there is an influence of writing interest on students' writing skills taught using PLEASE strategies. See Table 13.

Table 13

Significant Regression Coefficients Effect of Variable X (writing interest) on Y variable (writing descriptive using PLEASE strategy)

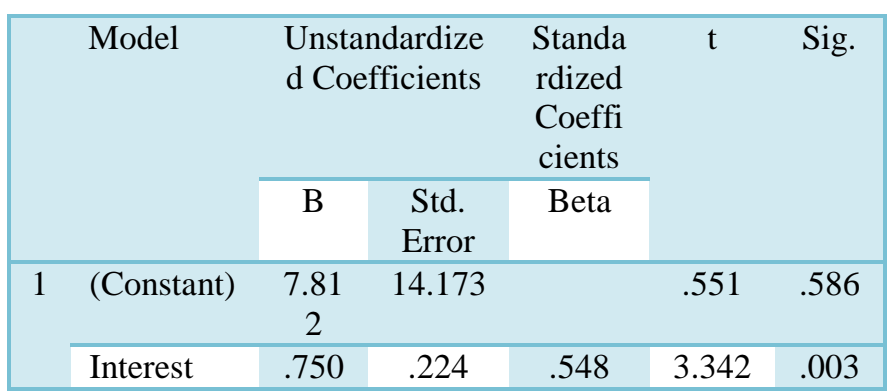




\section{DISCUSSION}

To strengthen the value of this research, there were some discussions explained based on the data analyses. First, at the first meeting before the treatment, the groups (experimental and control) were given the pretest. The result showed that the mean score of the experimental group in the pretest was 41.04 and mean score of the control group in the pretest was 44.14. Then, students of the experimental group were given treatment by PLEASE strategy. At the last meeting, the experimental and control groups were given the posttest, as a result, the mean score of posttest in the experimental group was 50.71 and in the control group was 45.54. The result of pretest and posttest in both groups indicated that the students of the experimental group had better scores than the students of the control group.

Moreover, the result of the independent sample t-test showed that tobtained was higher than t-table $(2.57>2.00)$, it can be concluded that null hypothesis (Ho) was rejected and the alternative hypothesis (Ha) was confirmed. It could be said that the seventh-grade students' achievement in writing descriptive text was significantly improved by using PLEASE strategy at SMP Negeri 2 Kayuagung. The students who were taught by using PLEASE strategy had better improvement in terms of their writing achievement to the guidance of writing descriptive text using PLEASE strategy. Following this strategy, the students picked the topic, audience and type of the paragraph they planned to write. Then, they were encouraged to write by selecting an interesting topic. After that, they generated a list of ideas they planned to include in their writing and to evaluate their list to see if it was necessary to add more ideas. Next, they activate the paragraph by constructing a topic sentence, adding supported sentences using their list of ideas. Finally, they wrote a conclusion. After the students had finished their composition, they were encouraged to evaluate their work by revising their ideas and editing their mistakes. The students followed the PLEASE strategy several times so that they were accustomed to writing descriptive text more carefully to produce a good descriptive writing text. The result of the study was supported by Akincilar (2010, p.53) who said that PLEASE strategy is effective to improve the students' ability in writing a paragraph.

On the contrary, the students' distribution score who were taught descriptive text by using PLEASE strategy was slightly increased. Out of 28 students, 2 students were at an excellent level and 3 students were at good level. Meanwhile, the rest of the students were at mediocre, poor, and very poor levels. The data were obtained 
due to the limitation of the time and the lack of the students' level proficiency. In fact, the teacher had already taught descriptive writing text using PLEASE strategy intensively and forced the students to write descriptive text.

Second, the students writing interest which compared to the result of students writing descriptive text showed that there is no influence of writing interest on the ability to write student descriptive texts. (the score t-obtained the writing variable is 1.14 at a significant of 0.26). In other words, the null hypothesis (Ho2)was rejected and the alternative hypothesis (Ha2) was accepted. The result of the data indicated that the students who were taught descriptive text without the treatment were lack of writing interest. The students did not have a writing interest because they learned writing only listening to the teacher explanation. Besides, they tended to avoid learning writing because they had difficulty to share their ideas in the written form.

Third, the result showed that the score of the writing variable was 3.34 at a significant level of 0.003 . It indicated that there was a relationship between the independent variable and the dependent variable. In other words, there was an influence of writing interest on students' writing skills taught using PLEASE strategies (Ha3 hypothesis was accepted).
At the first time, the students who were taught descriptive writing by using PLEASE strategy had low motivation to learn writing. It could be seen when they were asked to write descriptive text, they said that they were lazy to write and the result of the questionnaire showed that they had no writing interest. Moreover, when the students were given treatment (PLEASE strategy), they were encouraged to write descriptive text so that they could write a descriptive text based on the generic structure of the text and had positive writing interest.

\section{CONCLUSION}

Based on the analysis data using independent sample t-test, the result showed that t-obtained was higher than t-table $(2.57>2.00)$. In other words, there was a significant difference in writing achievement between the students who were taught descriptive text by using PLEASE strategy and that of those who were not. The students who were taught by using PLEASE strategy had better improvement in terms of their writing achievement due to the guidance of writing descriptive text using PLEASE strategy.

The students' writing interest who were not given treatment showed that there was no effect of writing interest on the ability to write descriptive texts (the score $\mathrm{t}$ - 
obtained the writing variable was 1.14 at a significant of 0.26). The result indicated that the students who were taught descriptive text without the treatment were lack of writing interest. The students did not have a writing interest because they learned writing only listen to the teacher explanation.

The students' writing interest who were given treatment using PLEASE strategy showed the score of the writing variable was 3.34 at a significant level of 0.003. It indicated that there was a relationship between the independent variable and the dependent variable. In other words, there was an effect of writing interest on students' writing skills taught using PLEASE strategy.

\section{REFERENCES}

Akincilar, V. (2010). The effect of “PLEASE” strategy training through the self- regulated strategy development (SRSD) model on fifth grade EFL students' descriptive writing: Strategy training on planning, middle east technical university. Retrieved November 14, 2016 from http://etd.lib.metu.edu.tr/upload/3/126 11947/index.pdf .

Boyle, J., \& Scanion, D. (2010). Methods and strategies for teaching students with mild disabilities. Wadsworth:

Cencage Learning

Brownell, M.T., Smith, S.J., Corckett, J.B. \& Griffin C.C. (2012). Inclusive instruction. New York, NY: The Guilford Press.

Djamarah, S.B. (2008). Psikologi belajar. Jakarta: PT. Rineka Cipta.

Fraenkel, J. R. dan Wallen, N. E. (2009). How to design and evaluate research in education $\left(7^{\text {th }}\right.$ ed). New York: McGraw-Hill Companies, Inc

Hartas, D. (2010). Educational research and inquiry: Qualitative and quantitative approaches. Great Britain: Bloomsbury Publishing Pic.

Harmer, J. (2007). How to teach writing. England: Pearson Education Limited.

Husna, L., Zainil., \& Rozimela, Y. (2013). An analysis of students' writing skill in descriptive text at grade XI IPA 1 of MAN 2 Padang. Journal English Language Teaching, 1 (2), 1-16. Retrieved January 1, 2017 from http://ejournal.unp.ac.id/index.php/elt/ arrticle/download/4555/3600.

Iskandarwassid \& Sunendar, D. (2008). Strategi pembelajaran bahasa. Bandung: Program Pascasarjana UPI dan PT Remaja Rosdakarya.

Kompas. (2011). Tradisi menulis lebih rendah daripada minat baca. 
edukasi.kompas.com>read>2011/11/2

3. Diakses pada tanggal 20 Juni 2017.

Mather, N., Wendling, B.J. \& Robberts, R. (2009). Writing assessment and instruction for students with learning disabilities. San Fransisco: JosseyBass

Nurudin. (2010). Dasar-dasar penulisan. Malang: UMM Press.

Rass, R.A. (2015). Challenges Face Arab Students' in Writing Well-Developed Paragraphs in English. English Language Teaching, 8 (10), 49-50. Retrieved January 17, 2017 from http://files.eric.ed.gov/fulltext/EJ1079 082.pdf.

Sinambela, M.\& Sinulingga, J. (2013). Improving Students' Achievement in Writing Hortatory Exposition Text through PLEASE Strategy. Journal Unimed. Retrieved June 6, 2018 from journal.unimed.ac.id $>$ article $>$ downloa d.

Sinurat, E.B. \& Alicia, D. (2013). Using Pens and COPS Strategy in Teaching Writing Procedure Text at Senior High School Students. Journal Mahasiswa Bahasa Inggris Genap 2(2). Retrieved October 16, 2017 from http://id.portalgaruda.org/?ref=browse $\& \bmod =$ viewarticle $\&$ article $=182773$.

Suparno. (2008). Keterampilan Dasar Menulis. Jakarta: Universitas Terbuka
Suter, W.N. (2012). Introduction to educational research: A critical thinking approach. Calfornia: SAGE

Tarigan, G.H. (2008). Menulis sebagai suatu keterampilan berbahasa. Bandung: Angkasa.

Terwilliger, A. B. (2011). Descriptive Essay Guidelines: Structuring a Descriptive Essay. Writing Handout E-7,1-3, Retrieved June 16, 2018 from http://gg.gg/3t89d.

Welch, M. (1992).The PLEASE strategy: A metacognitive learning strategy for improving the paragraph writing of students with mild learning disabilities. Learning Disability Quarterly, 15, 119-127.

Yagelski, R.P. (2015). The essential writing ten core concepts. Stamford: Cengage Learning. 